\title{
2. Pacific journalism solidarity in the face of overwhelming forces
}

Commentary: The Melanesian Media Freedom Forum (MMFF) notes democracy is in retreat and journalists like Victor Mambor (West Papua), Scott Waide (Papua New Guinea) and Dan McGarry (Vanuatu) are carrying the baton for media freedom. There has been a global reversal for a free press that has spanned countries in every region, including long-standing democracies like the United States and consolidated authoritarian regimes like China and Russia. The pattern has been consistent and ominous.

Keywords: democracy, free press, media freedom, Melanesia, Melanesia Media Freedom Forum, West Papua

\section{FRED WESLEY \\ Editor-in-chief, The Fiji Times, Suva}

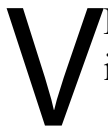

ICTOR MAMBOR cuts an unassuming figure. He stands at 1.75 metres in height and is a quiet man. He has a sprightly jump in his stride.

It's a bright and sunny Monday morning.

There's a slight breeze coming in over the Brisbane river, cutting its way across to the balcony of Room S02-7 at Griffith University.

In the distance, what appears to be fog, is, however, smoke emanating from the Queensland bush fires.

Media reports 150 fires rage across New South Wales and Queensland, feeding tinder-dry conditions.

High temperatures and volatile winds are aiding the fires in Queensland, sending forth white smoke hovering above Brisbane.

Residents are forced to remain indoors for two days. Inside the lecture room, Victor mingles with the journalists. The enclosed room kept the smoke out and important discussions in.

This was the first meeting of the Melanesian Media Freedom Forum (MMFF).

Journalists travelled from Bougainville, Fiji, Papua New Guinea, Solomon Islands, Vanuatu - and Victor from West Papua — for the two-day forum.

On Saturday, a measles outbreak in a south Brisbane school had topped Brisbane news headlines. 


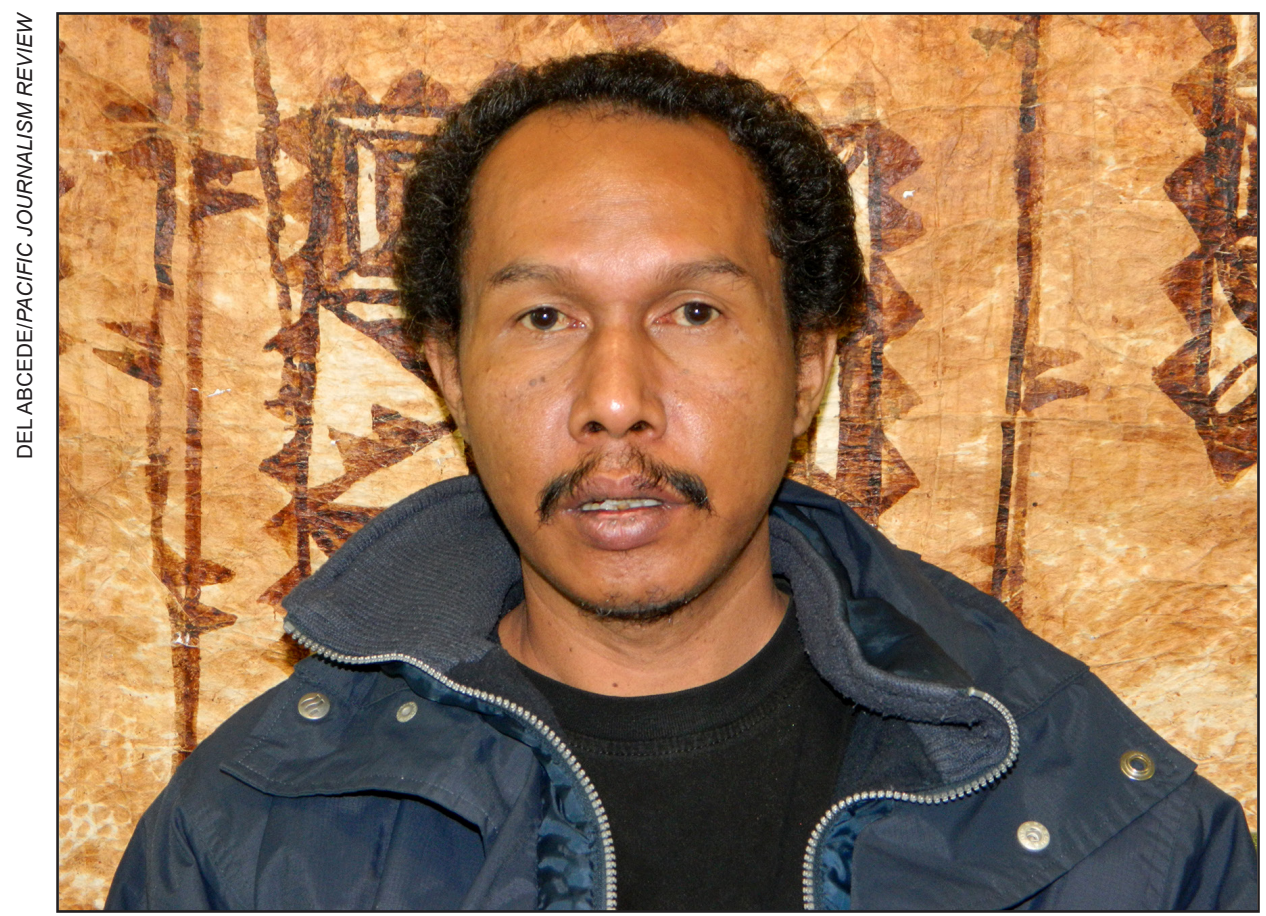

Figure 1: Victor Mambor: faced intimidation and harassment for reporting about an internet blackout sanctioned by the Indonesian government.

But the same day, 24 August 2019, The Jakarta Post reported that Mambor had faced intimidation and harassment for reporting about an internet blackout sanctioned by the Indonesian government amid escalating protests in Papua and West Papua (Syakriah, 2019).

The Indonesia Alliance of Independent Journalists (AJI Indonesia), released a report, stating Mabor, the editor of Jubi newspaper, an AJI member and correspondent for The Jakarta Post, had been harassed by a social media user with the Twitter handle@antilalat.

A day later, the AJI reported, the UK-based law firm Doughty Street Chambers representing Mambor had filed an urgent appeal to UN Special Rapporteur on Freedom of Expression David Kaye regarding internet blocking in the provinces amid protests.

AJI Indonesia's advocacy head Sasmito Madrim said that @antilalat had accused Mambor of having links to the Free Papua Movement (OPM) in the provinces and abroad, as well as being an informant for Indonesian lawyer Veronica Koman, who was a lawyer for the West Papua National Committee.

Sasmita said the accusations against Mambor were groundless since he had merely been doing his job as a reporter objectively while complying with the journalism code of ethics. Sasmito said: 
The AJI would like to remind social media users and law enforcers that journalists, in doing their jobs, are protected by Law No. 40/1999 on the press. If anyone thinks there is incorrect journalistic material published in the media, the Press Law regulates the mechanisms that ensure a journalistic right to reply and corrections, and allow the filing of complaints to the Press Council. (Syakriah, 2019)

Radio New Zealand took up the report on August 26 (Urgent UN appeal, 2019). The Indonesian government, it reported, deployed 1000-extra military and police personnel to Papua at the time, as some of the protests turned violent. The Ministry of Communications announced it had throttled internet access to parts of Papua.

According to the RNZ report, this came as large protests spread through Papua in response to racist harassment of Papuans in Javanese cities. The ministry said at the time, blocking of the internet would continue until the circumstances in Papua were 'absolutely normal'.

Mambor insisted the blockage violated international human rights law, meaning coverage of the protests was difficult. The ministry said that although the situation in some parts of Papua had begun to gradually recover, 'distribution and transmission of information hoax, hoaxes, provocative and racist remains high'.

As a consequence, local media outlets were restricted in their ability to send photographs and videos of the protests.

The Committee to Protect Journalists got involved, urging Indonesian authorities to immediately restore internet access to the Papua region (Indonesia should restore internet access, 2019). Its senior Southeast Asia representative, Shawn Crispin, claimed the shutdown aimed to block the free flow of information in a region notorious for state-sponsored rights abuses.

Back at Griffith University, Mambor's quiet demeanour slowly evaporated as discussions turned to media freedom. It's a topic close to the heart of these regional journalists who had been invited to be part of this historic meeting in Brisbane.

In November last year, the $\mathrm{ABC}$ reported about a senior Papua New Guinean journalist who was suspended after airing a story critical of government spending, being reinstated by broadcaster EMTV following a widespread public backlash.

Scott Waide, the Lae City bureau chief was suspended for airing a report from a New Zealand television station criticising PNG's purchase of 40 luxury Maseratis (EMTV suspends senior journalist Scott Waide, 2018). The report came in the wake of anger over government spending during the Asia Pacific Economic Cooperation (APEC) conference. The government was accused of a cover up by the Opposition.

The week before the MMFF gathering, The Guardian reported that the Vanuatu government had refused to renew Vanuatu Daily Post's long serving director Dan McGarry's work permit (Davidson, 2019). Having spent 16 years living 


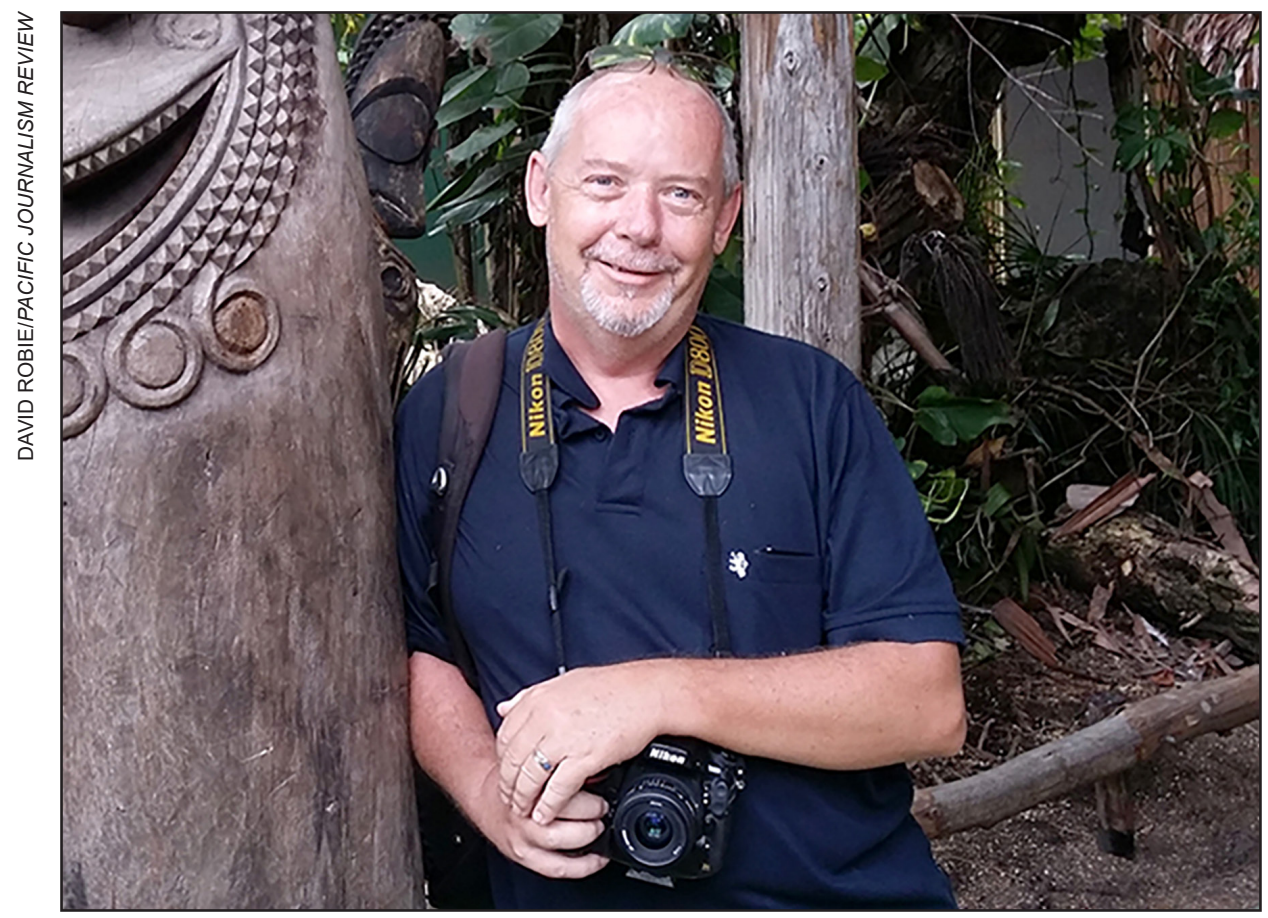

Figure 2: Dan McGarry (Vanuatu Daily Post): Lived in Vanuatu for 16 years, but declined a work permit renewal because of his newspaper's reporting on government activities, causing it 'discomfort'.

and working in Vanuatu, McGarry's application to renew his work permit was refused. It meant McGarry, who was married to a Ni-Vanuatu, and their children, would have to leave Vanuatu.

McGarry believed the turn of events stemmed from the newspaper's reporting on the government's activities, causing it 'discomfort'. It's interesting that Freedom House has recorded what it termed the 13th consecutive year of decline in global freedom (Democracy in retreat, 2019).

The reversal, it pointed out, had spanned a variety of countries in every region, from long-standing democracies like the United States to consolidated authoritarian regimes like China and Russia. It stated that the overall losses were still shallow compared with the gains of the late 20th century, but the pattern was consistent and ominous. Democracy is in retreat.

More authoritarian powers, it pointed out, were now banning opposition groups or jailing their leaders, dispensing with term limits, and tightening the screws on any independent media that remained. Most troublingly, it stated, even long-standing democracies had been shaken by populist political forces that rejected basic principles like the separation of powers and targeted minorities for discriminatory treatment. 
However, it believes the promise of democracy remains real and powerful. It stated that not only defending it, but broadening its reach is one of the great causes of our time.

Journalists like Waide, McGarry, and Mambor were at home. The forum discussions focused on an area of their chosen profession that they understood intimately, and were passionate about.

Dr Tess Newton Cain said the idea for the forum started with a conversation over pizza with SBS Pacific journalist Stefan Armbruster.

'We were reflecting on what we had heard from journalists in the region about the threats to media freedom that they were facing,' Dr Newton Cain said.

'We felt that there would be value in getting some of the senior people together to join forces, intellectually and emotionally, and see whether they could work out how to better meet those challenges in the future.

'We road tested the concept with some key people in Fiji, Solomon Islands and Vanuatu and got the sense that it was something that would be welcomed and that people felt a safe and neutral space was needed - hence Brisbane was chosen as the location.'

Griffith University agreed to be the institutional home for the event and so in July 2018 the decision was made to proceed.

'I was struck by how the participants grabbed the opportunity and made it work for them. It was always our intention to create the space and hand it over to the media practitioners to use it as they wanted to,' Dr Newton Cain said.

'I think this is something of a new approach and it was a bit of a risk. What if no-one wanted to say anything? What if people got bored and wandered off?

'Hearing people say that they were pleased that they had come and that they gained something from the experience was really wonderful.'

Dr Newton Cain had not been prepared for emotional energy that this event would create.

'I heard a couple of people say, "it's so good to realise we're not on our own in this". I felt really grateful that the participants had trusted us to deliver what we had promised and embraced the opportunity in the spirit with which it was offered.'

'As you know, Sean Dorney is living with motor neurone disease and he has to be careful that he doesn't overdo things. At the end of the two days he said to me: "Pauline kept asking me if I was OK, if I was getting tired but I said to her 'being here and being with these journalists is giving me energy, it's giving me a boost'.",

Hosting the event was a big responsibility, with much of the organisation of the event done in downtime.

'I think I can speak for all of us when I say that it's been a pleasure and a privilege to have been part of what was such a special event and and we are very 
excited to see what comes next,' Dr Newton Cain said.

Outside the lecture room, the white smoke hung heavy in the distance.

In the din of the afternoon traffic in Brisbane there was a sense of appreciation in the room. There was motivation and solidarity to strive to work together for press freedom.

\section{References}

Davidson, H. (2019, November 8). The Guardian. Retrieved from https://www.theguardian.com/world/2019/nov/08/attack-on-the-media-vanuatu-newspaper-boss-has-workvisa-refused

Democracy in retreat: Freedom in the world 2019 (2019). Freedom House. Retrieved from https://freedomhouse.org/report/freedom-world/freedom-world-2019/democracy-in-retreat

EMTV suspends senior journalist Scott Waide over NZ Maserati news story (2018, November 25). Asia Pacific Report-Pacific Media Watch. Retrieved from https:// asiapacificreport.nz/2018/11/25/emtv-suspends-senior-journalist-scott-waide-overmaserati-news-story/

Indonesia should restore internet access in restive Papua region (2019, August 21). Committee to Protect Journalists. Retrieved from https://cpj.org/2019/08/indonesiarestore-internet-papua.php

Syakriah, A. (2019, August 24). West Papuan journalist faces intimidation, files appeal to UN. The Jakarta Post. Retrieved from https://www.thejakartapost.com/ news/2019/08/24/west-papua-journalist-faces-intimidation-files-appeal-to-un.html

Urgent UN appeal filed over blocking of internet in Papua (2019, August 26). RNZ Pacific. Retrieved from https://www.rnz.co.nz/international/pacific-news/397501/ urgent-un-appeal-filed-over-blocking-of-internet-in-papua

Fred Wesley is editor-in-chief of The Fiji Times and was awarded the news media executive of the year prize at the Asia Pacific Media Awards after his courageous stand against the Fiji government in a sedition case filed against his newspaper. The Fiji Times, the oldest and the most influential newspaper in Fiji, celebrated 150 years in 2019. An earlier version of this article was published in the Fiji Times on 16 November 2019 under the title 'Threats to media freedom.

fwesley@fijitimes.com.fj 